\title{
Emergency room visits due to external causes and alcohol consumption - Capitals and the Federal District, Brazil, 2011
}

\author{
Márcio Dênis Medeiros Mascarenhas ${ }^{1}$ \\ Alice Cristina Medeiros das Neves ${ }^{1}$ \\ Rosane Aparecida Monteiro ${ }^{1}$ \\ Marta Maria Alves da Silva ${ }^{1}$ \\ Deborah Carvalho Malta ${ }^{1}$
}

\footnotetext{
${ }^{1}$ Departamento de Vigilância de Doenças e Agravos Não Transmissíveis e Promoção da Saúde, Ministério da Saúde. Setor SAFS Quadra (Setor de Administração Federal Sul) Edifício Premium/Torre 1/Bloco F/Sala 16 , Zona Cívico-Administrativa. 70070-600 Brasília DF Brasil.mdm.mascarenhas@ gmail.com
}

\begin{abstract}
The study objective was to describe the profile and factors related to alcohol consumption among emergency room visits by external causes. It is a cross-sectional study with data from the Survey of Violence and Injuries in Emergency between September and October 2011, in 24 state capitals and the Federal District. Statistical analysis were performed for all cases treated in selected services, comparing the characteristics of the victims, according to the statement of alcohol consumption. 33,289 visits to emergency rooms by external causes in the population above 18 years of age were included. The prevalence of self-reported statement of alcohol consumption among these services was $14.9 \%$ for the 24 capitals and the Federal District, and was significantly higher among visits by violent causes than by accidents. For both accidents and violence the associated causes were victims male, black/brown, less educated, members of specific populations, occurrences on public roads. The results support global discussions on the importance of establishing policies and legal measures to restrict the consumption of alcohol and vehicular direction, control advertising of alcoholic beverages, and laws normalizing the functioning of sales points of alcoholic beverages.

Key words Alcohol, Accidents, Violence, External causes, Emergency medical services
\end{abstract}




\section{Introduction}

The harmful use of alcohol is considered one of the most important risk factors affecting the health status of different population groups. According to estimates by the World Health Organization (WHO), this habit is responsible for approximately 2.3 million premature deaths annually worldwide. Injuries from external causes (accidents and violence) represent more than one-third of all deaths due to alcohol consumption and affect not only the direct consumer but other groups, including pedestrians and cyclists, who can be injured by an intoxicated driver ${ }^{1}$.

External causes of morbidity are of great importance in public health because of their magnitude and impact on people's lives, particularly in developing countries ${ }^{2,3}$. According to the Pan American Health Organization $(\mathrm{PAHO})^{4}$, external factors are the main cause of reduced lifespan in two-thirds of the American countries, and traffic accidents, homicides, and suicides are among the five leading causes of premature death.

Alcohol consumption has been associated with many different types of injuries from external causes, including those related to traffic, falls, burns, sports, labor, and interpersonal and self-inflicted violence. In the Americas, violence and injuries due to traffic deserve attention as a public health problem 5 .

The first national survey on the patterns of alcohol consumption in the Brazilian population $^{6}$ was conducted between 2005 and 2006 and found that $52 \%$ of Brazilians over 18 years of age consumed alcohol at least once a year. This rate was $65 \%$ among men and $41 \%$ among women. In the group of adults who consumed alcohol, $60 \%$ of men and $33 \%$ of women consumed $\geq 5$ drinks on the occasion of highest consumption in the last year. Of all adult men, $11 \%$ consumed alcohol every day, and 28\% consumed alcohol 1-4 times a week ${ }^{6}$. With the implementation of the telephone-based surveillance of risk and protective factors for chronic diseases system (VIGITEL), in which alcohol consumption is one of the research topics, it was possible to evaluate the alcohol consumption pattern in the Brazilian adult population. According to Moura and Malta ${ }^{7}$, VIGITEL data showed that, in 2006, the habitual consumption of alcoholic beverages reached $38.1 \%$ of the study population, and alcohol abuse reached $16.2 \%$ of the population; these rates were higher in men compared with women. Since then, alcohol abuse has increased gradually in both genders.
In 2006, the Ministry of Health established the Brazilian Surveillance System for Violence and Accidents (Sistema de Vigilância de Violências e Acidentes/VIVA). This surveillance system is structured into two components: 1) surveillance of the cases of violence and accidents in hospital emergency units, aiming to characterize emergency care for external causes, and 2) surveillance of the cases of sexual, domestic and/or other interpersonal violence, which considers the legal requirements for notification of violence against children, adolescents, women, and older adults ${ }^{8}$.

Injuries from external causes attributed to alcohol consumption have increased worldwide, a problem that is more obvious in the health care provided in emergency services. The assessment of emergency care constitutes an effective strategy to collect relevant information on the correlation between alcohol use and external causes and fosters the development of public policies aimed at more effective and large-scale interventions ${ }^{1}$.

This study aimed to describe the profile and factors associated with alcohol consumption in emergency care for external causes based on data obtained from the VIVA 2011 survey conducted in 24 state capitals and the Federal District.

\section{Methods}

This cross-sectional study used data obtained from the VIVA survey, conducted between September and November 2011 in 71 urgent and emergency care units from the Unified Health System (Sistema Único de Saúde/SUS) in the Federal District and in 24 Brazilian state capitals, except Manaus, in the state of Amazonas, and São Paulo, in the state of São Paulo, which did not conduct the survey for operational reasons. The inclusion of the selected units has been validated by the local teams according to the following criteria: 1) health care units authorized to provide urgent and emergency care services according to the National Register of Health Facilities (Cadastro Nacional de Estabelecimentos de Saúde/ CNES);2) availability of records on the number of hospitalizations due to external causes obtained from the Hospital Information System of the Unified Health System (Sistema de Informações Hospitalares/SIH/SUS); and 3) number of health care visits identified in the VIVA surveys conducted in 2006, 2007, and 20099-11.

For data collection, the period of 30 consecutive days was considered and divided into 12- 
hour shifts, totaling 60 work shifts, 30 during the daytime (7:00 a.m. to 6:59 p.m.) and 30 during the nighttime (7:00 p.m. to 6:59 a.m.). The procedure adopted for the selection of the work shifts was cluster sampling in a single-stage selection, and the shift was the primary sampling unit. The number of shifts drawn in each establishment was obtained as a function of the minimum sample size (2,000 per capital) and the average number of emergency care visits for external causes during working hours, assuming a coefficient of variation of $<30 \%$ and a standard error of $<3^{9-11}$.

All the victims of external causes who sought care for the first time in the urgent and emergency services in the shifts selected by casting lots and who agreed to participate in the study were eligible for the interview. Data were collected using a standardized form applied by trained personnel. The emergency care visits were divided into two groups according to intentionality: a) accident-defined as "an unintentional and avoidable event that causes physical and emotional injuries in domestic or social settings, including work, school, sports, and leisure"12 (traffic accidents, falls, burns, cuts, objects falling on the person, poisoning, suffocation, and drowning, among others), and b) violence-defined as "the use of force against a group or community that either results in or can potentially result in injury, death, psychological harm, developmental disability, or deprivation"3 (self-harm, abuse, and assault).

The self-report of alcohol consumption was obtained using the following question: Did you consume alcohol in the six hours prior to the event [which motivated you to seek this health care service]? The records of emergency care visits for external cases of patients aged $\geq 18$ years were included in the present analysis, considering the following variables:

a) Sociodemographic: gender (male, female), age group (18-29, 30-39, 40-59, $\geq 60$ years), ethnicity/skin color (white, black/brown [mixed], yellow/indigenous), education level $(0-8, \geq 9$ years), and specific population groups;

b) Event: place of occurrence (residences, public places, schools, recreational areas, businesses, industry/construction areas, etc.), nature of injury (no physical injury, bruise, cut/laceration/amputation, sprain/dislocation, fracture, trauma, other), body part affected (head/neck, chest/abdomen/pelvis, extremities, multiple organs/regions), self-report of alcohol use, type of event (accidents, violence), type of occurrence (assault/abuse, drowning, self-harm, injury from firearms, traffic accident, poisoning/intoxication, fall, injury from a sharp object, accident involving animals, suffocation/choking, collision against object/person, sprain, burn, object falling on the person, foreign body, compression between/within objects, other accidents);

c) Emergency visit: means of transportation to the hospital (on foot, private vehicle, SAMU [Serviço de Atendimento Móvel de Urgência (Mobile Emergency Care Service)]/ambulance/ rescue, bus/van, police car, etc.), period of visit (nighttime, daytime), day of visit (Monday to Friday, Saturday and Sunday), and outcome (discharge, admission, outpatient referral, evasion, death).

The analyses were performed for the total number of visits to the selected units by comparing the profile of the victims according to self-report of alcohol consumption. The null hypothesis of independence between the qualitative variables was assessed using the chi-square test and a significance level of 5\%. The prevalence ratios and 95\% confidence intervals were estimated using a Poisson regression. The "svy" module in Stata software version 11 (Stata Corp., College Station, TX, United States) was used, which is suitable for obtaining unbiased estimates when data are obtained from complex sampling designs.

The VIVA survey 2011 was approved by the National Research Ethics Committee (Comissão Nacional de Ética em Pesquisa-CONEP). Additional information on the sampling design, organization, and operationalization of the survey can be obtained from other publications ${ }^{9-11}$.

\section{Results}

In the VIVA survey 2011,33,289 urgent and emergency visits for external causes were evaluated in the population aged $\geq 18$ years with valid information on alcohol consumption in the six hours prior to the event that led the victim to seek medical care. Among these visits, the prevalence of self-reported alcohol consumption was $14.9 \%$ for all state capitals and the Federal District. Among the visits by victims of accidents, the prevalence of alcohol consumption was $11.4 \%$, varying between $5.1 \%$ in Macapá, in the state of Amapá, and $21.5 \%$ in Salvador, in the state of Bahia. For visits by victims of violence, the prevalence of alcohol consumption was $44.1 \%$, varying between $33.4 \%$ in Vitória, in the state of Espírito Santo, and $56.9 \%$ in Recife, in the state of Pernambuco. 
Figure 1 shows the distribution of the prevalence of self-reported alcohol consumption, according to each municipality and by event type.

Table 1 shows the distribution of self-reported alcohol consumption among the emergency visits for external causes. Alcohol consumption was significantly higher for the visits by victims of violence, primarily among those of male gender, among those aged 18-39 years, and among those who declared themselves of black/brown ethnicity. Moreover, alcohol consumption was higher among individuals with less education, for members of specific population groups (villagers, Quilombola communities, homeless), and for emergency visits at night and on weekends.

Table 2 shows the factors associated with alcohol consumption stratified by type of event (accident or violence). Among the visits for accidents, the prevalence of self-reported alcohol consumption was significantly higher among men, among those who declared themselves of black/brown ethnicity, among those with low education levels, and among members of specific population groups. Alcohol consumption was significantly lower among older people compared with younger groups. There was a higher percentage of self-reported alcohol consumption among patients who experienced injuries in public places compared with injuries that occurred in residences. Among the visits by victims of violence, self-reported alcohol consumption prevailed among men, among those of black/brown and yellow/indigenous ethnicities, among those with lower education levels, and among those from specific population groups. The percentage of self-reported alcohol consumption was higher among patients who experienced events in public places, recreational areas, and businesses compared with events that occurred in residences.

Table 3 presents the characteristics of emergency visits for external causes and their association with alcohol consumption by type of event. Among the emergency care visits for accidents, the percentage of self-reported alcohol consumption was higher among patients who experienced accidents that affected body segments such as head/neck and multiple organs/ regions. The highest percentage of self-reported alcohol consumption was observed among individuals requiring the use of different means of public transportation to the hospital, among those needing care at night and on weekends, and among those whose visits resulted in hospitalization, outpatient follow-up, or abandonment.

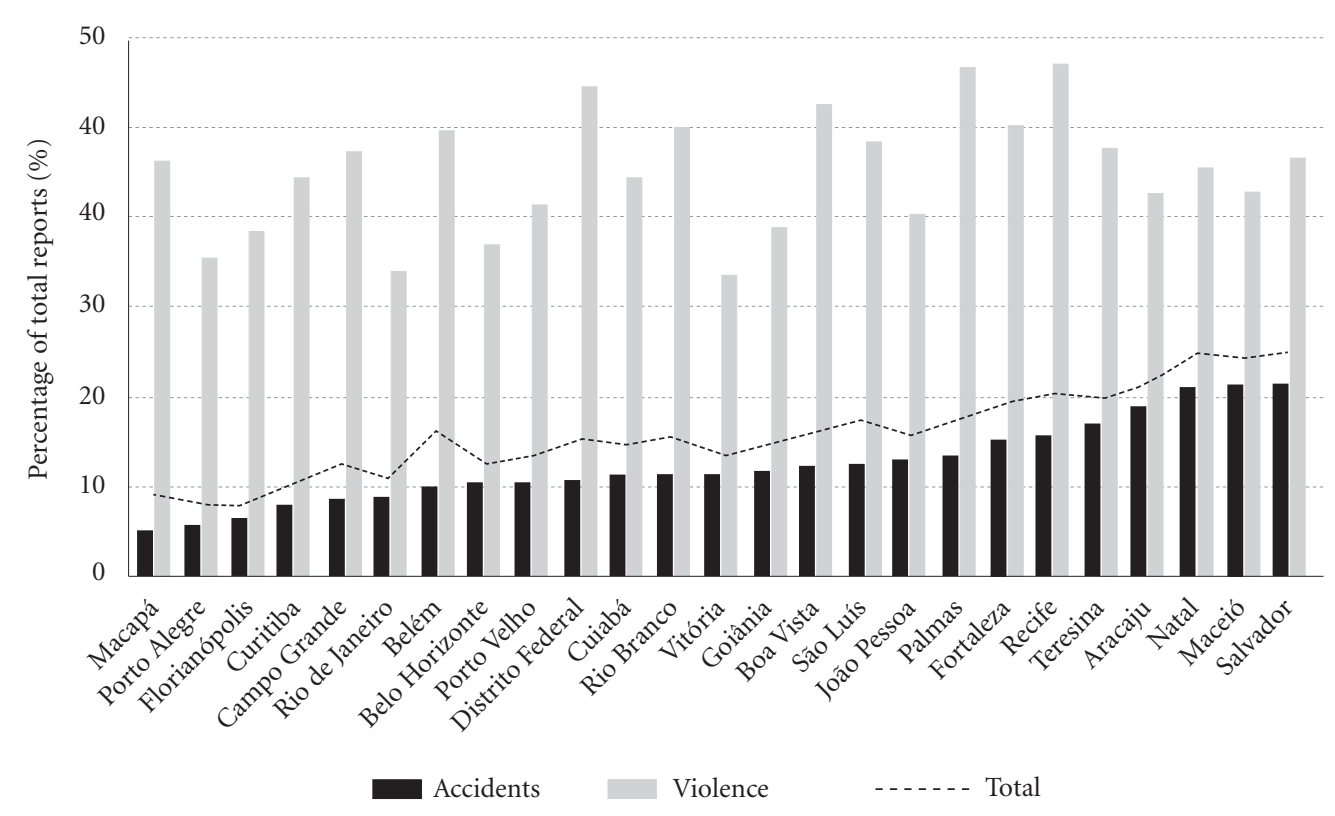

Figure 1. Distribution of self-reported alcohol consumption among patients who received emergency care permunicipality - Capitals ${ }^{\mathrm{a}}$ and the Federal District, Brazil, 2011. 
Table 1. Distribution of self-reported alcohol consumption among patients who received emergency care according to selected characteristics - Capitals ${ }^{\mathrm{a}}$ and the Federal District, Brazil, 2011.

\begin{tabular}{|c|c|c|c|c|}
\hline \multirow[b]{2}{*}{ Characteristics } & \multirow[b]{2}{*}{$\begin{array}{c}\text { Total } \\
(\mathbf{n}=33,289)^{b} \\
\%^{c}\end{array}$} & \multicolumn{2}{|c|}{ Alcohol consumption } & \multirow[b]{2}{*}{$\underset{\text { value }}{p}$} \\
\hline & & $\begin{array}{c}\text { Yes } \\
(\mathbf{n}=5,079)^{b} \\
\%^{c}\end{array}$ & $\begin{array}{c}\text { No } \\
(\mathrm{n}=28,210)^{\mathrm{b}} \\
\%^{\mathrm{c}}\end{array}$ & \\
\hline Total & 100.0 & 14.9 & 85.1 & - \\
\hline Type of event & & & & 0.000 \\
\hline Accident & 89.4 & 11.4 & 88.6 & \\
\hline Violence & 10.6 & 44.1 & 55.9 & \\
\hline Gender & & & & 0.000 \\
\hline Female & 34.3 & 7.7 & 92.3 & \\
\hline Male & 65.7 & 18.7 & 81.4 & \\
\hline Age group (years) & & & & 0.000 \\
\hline $18-29$ & 39.1 & 16.6 & 83.4 & \\
\hline $30-39$ & 23.7 & 16.9 & 83.1 & \\
\hline $40-59$ & 26.0 & 14.5 & 85.5 & \\
\hline$\geq 60$ & 11.2 & 5.8 & 94.2 & \\
\hline Ethnicity/skin color & & & & 0.000 \\
\hline White & 31.8 & 10.8 & 89.2 & \\
\hline Black/brown (mixed) & 66.0 & 16.9 & 83.1 & \\
\hline Yellow/Indigenous & 2.1 & 14.9 & 85.1 & \\
\hline Education (years) & & & & 0.000 \\
\hline$\geq 9$ & 50.2 & 12.0 & 88.0 & \\
\hline $0-8$ & 49.8 & 16.1 & 83.9 & \\
\hline Specific population groups ${ }^{\mathrm{d}}$ & & & & 0.000 \\
\hline No & 97.7 & 14.7 & 85.3 & \\
\hline Yes & 2.3 & 24.7 & 75.3 & \\
\hline Period of visit & & & & 0.000 \\
\hline Daytime & 60.3 & 7.9 & 92.1 & \\
\hline Nighttime & 39.7 & 25.3 & 74.7 & \\
\hline Day of visit & & & & 0.000 \\
\hline Monday to Friday & 70.1 & 9.8 & 90.2 & \\
\hline Saturday and Sunday & 30.0 & 26.7 & 73.3 & \\
\hline
\end{tabular}

Source: MS, SVS, Brazilian Surveillance System for Violence and Accidents (Sistema de Vigilância de Violências e Acidentes-VIVA

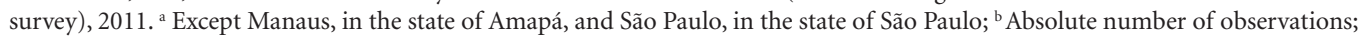
${ }^{\mathrm{c}}$ Weighted percentage; ${ }^{\mathrm{d}}$ Includes gypsies, Quilombolas, villagers, and homeless people. ${ }^{*}$ Pearson chi-square test.

With regard to emergency visits by victims of violence, the percentage of self-reported alcohol consumption was higher among patients whose events affected the head/neck, among individuals requiring the use of different means of transportation to the hospital, including private vehicles and SAMU/ambulance/rescue, and among individuals needing care at night and on weekends. No significant difference was observed in the prevalence of alcohol consumption between the victims of violence according to the outcome of the emergency visit.

Figure 2 shows the distribution of the prevalence of self-reported alcohol consumption according to the type of occurrence, using as ref- erence the prevalence values obtained for visits due to compression between/within objects. The highest prevalence of self-reported alcohol consumption was observed among the victims of aggression/abuse, drowning, self-harm, injury by firearms, traffic accidents, poisoning/intoxication, and falls.

\section{Discussion}

Alcohol consumption in emergency visits for external causes was self-reported in more than onetenth of the accidents and in approximately half of the cases of violence, indicating the high mag- 
Table 2. Prevalence (\%) of self-reported alcohol consumption among patients who received emergency care according to sociodemographic characteristics and location of the event, stratified by type of occurrenceCapitalsa and the Federal District, Brazil, 2011.

\begin{tabular}{|c|c|c|c|c|}
\hline \multirow[t]{2}{*}{ Characteristics } & \multicolumn{2}{|c|}{$\begin{array}{c}\text { Accidents } \\
\text { Alcohol consumption } \\
(\mathrm{n}=3,434)^{\mathrm{b}}\end{array}$} & \multicolumn{2}{|c|}{$\begin{array}{c}\text { Violence } \\
\text { Alcohol consumption } \\
(\mathrm{n}=1,645)^{\mathrm{b}}\end{array}$} \\
\hline & $\%^{\mathrm{c}}$ & PR $(95 \% \mathrm{CI})$ & $\%^{c}$ & PR (95\% CI) \\
\hline \multicolumn{5}{|l|}{ Gender } \\
\hline Female & 5.7 & 1.00 & 28.8 & 1.00 \\
\hline Male & 14.6 & $2.57(2.26-2.91)$ & 50.3 & $1.75(1.51-2.02)$ \\
\hline \multicolumn{5}{|l|}{ Age group (years) } \\
\hline $18-29$ & 12.7 & 1.00 & 43.3 & 1.00 \\
\hline $30-39$ & 12.8 & $1.00(0.91-1.11)$ & 46.5 & $1.07(0.97-1.19)$ \\
\hline $40-59$ & 11.6 & $0.91(0.83-1.01)$ & 44.7 & $1.03(0.92-1.16)$ \\
\hline$\geq 60$ & 4.5 & $0.35(0.29-0.42)$ & 34.9 & $0.81(0.61-1.06)$ \\
\hline \multicolumn{5}{|l|}{ Ethnicity/skin color } \\
\hline White & 8.4 & 1.00 & 36.4 & 1.00 \\
\hline Black/brown (mixed) & 13.0 & $1.54(1.35-1.76)$ & 46.5 & $1.28(1.11-1.46)$ \\
\hline Yellow/Indigenous & 10.9 & $1.29(0.97-1.71)$ & 52.5 & $1.44(1.10-1.89)$ \\
\hline \multicolumn{5}{|l|}{ Education (years) } \\
\hline$\geq 9$ & 9.6 & 1.00 & 37.3 & 1.00 \\
\hline $0-8$ & 12.1 & $1.26(1.16-1.37)$ & 46.8 & $1.26(1.14-1.38)$ \\
\hline \multicolumn{5}{|l|}{ Specific population groups ${ }^{\mathrm{d}}$} \\
\hline No & 11.3 & 1.00 & 43.6 & 1.00 \\
\hline Yes & 17.2 & $1.52(1.22-1.88)$ & 57.4 & $1.32(1.06-1.64)$ \\
\hline \multicolumn{5}{|l|}{ Place of occurrence } \\
\hline Residence $^{e}$ & 7.4 & 1.00 & 32.6 & 1.00 \\
\hline Public places & 18.5 & $2.51(2.27-2.78)$ & 46.3 & $1.42(1.26-1.59)$ \\
\hline Recreational areas & 8.9 & $1.21(0.98-1.50)$ & 46.7 & $1.43(1.08-1.91)$ \\
\hline Businesses & 4.5 & $0.61(0.48-0.77)$ & 66.8 & $2.05(1.82-2.30)$ \\
\hline Schools & 1.7 & $0.23(0.04-1.41)$ & 5.1 & $0.16(0.04-0.65)$ \\
\hline Industry/construction areas & 1.2 & $0.16(0.10-0.27)$ & 9.5 & $0.29(0.08-1.04)$ \\
\hline Other & 9.2 & $1.25(0.96-1.63)$ & 36.6 & $1.12(0.77-1.62)$ \\
\hline
\end{tabular}

Source: MS, SVS, Brazilian Surveillance System for Violence and Accidents (Sistema de Vigilância de Violências e Acidentes-VIVA survey), 2011. ${ }^{a}$ Except Manaus, in the state of Amapá, and São Paulo, in the state of São Paulo; ${ }^{\mathrm{b}}$ Absolute number of observations; ${ }^{\mathrm{c}}$ Weighted percentage; ${ }^{\mathrm{d}}$ Includes gypsies, Quilombolas, villagers, and homeless people; ${ }^{\mathrm{e}}$ Includes residences and collective housing. PR: prevalence ratio; 95\% CI: 95\% confidence interval. Statistically significant differences $(\mathrm{p}<0.05)$ are in bold.

nitude of the problem. Considering the number of accidents and cases of violence, alcohol consumption was associated with the following characteristics: male gender, black/brown ethnicity, lower education level, belonging to specific population groups, occurrence of the event in public places, and emergency visits at night and on weekends.

Alcohol consumption is an adapted behavior encouraged in most cultures and communities and is associated with celebrations, festivities, and religious ceremonies, among other cultural manifestations ${ }^{13}$. The WHO estimates that approximately 770,000 deaths occur annually ( $1.5 \%$ of all deaths worldwide) due to the use of alcohol, at an annual cost of approximately
$0.5 \%-2.7 \%$ of the gross domestic product (GDP) in different countries ${ }^{13,14}$.

Excessive alcohol consumption is an important public health problem that directly affects morbidity and mortality. There are several patterns of alcohol consumption, including chronic consumption, that can cause harm and dependence and can result in mental, liver, and cardiovascular diseases, along with cancer and other complications ${ }^{13-15}$. A regular usage pattern involves the consumption of excessive amounts of alcohol in a short period of time, a practice known in the literature as "binge drinking". The term is used worldwide to define "heavy episodic drinking" ${ }^{\prime \prime}$. The problems arising from the episodic and acute use of alcohol are also import- 
Table 3. Prevalence (\%) of self-reported alcohol consumption among patients who received emergency care according to the characteristics of the emergency visit, stratified by type of occurrence-Capitals $s^{\mathrm{a}}$ and the Federal District, Brazil, 2011.

\begin{tabular}{|c|c|c|c|c|}
\hline \multirow{2}{*}{ Characteristics } & \multicolumn{2}{|c|}{$\begin{array}{c}\text { Accidents } \\
\text { Alcohol consumption } \\
(\mathrm{n}=3,434)^{\mathrm{b}}\end{array}$} & \multicolumn{2}{|c|}{$\begin{array}{c}\text { Violence } \\
\text { Alcohol consumption } \\
(\mathrm{n}=1,645)^{\mathrm{b}}\end{array}$} \\
\hline & $\%^{\mathrm{c}}$ & PR $(95 \%$ CI $)$ & $\%^{c}$ & PR $(95 \%$ CI $)$ \\
\hline \multicolumn{5}{|l|}{ Body segment affected } \\
\hline Extremities & 8.8 & 1.00 & 40.4 & 1.00 \\
\hline Thorax/abdomen/pelvis & 8.9 & $1.01(0.87-1.18)$ & 42.1 & $1.04(0.89-1.21)$ \\
\hline Head/neck & 19.1 & $2.17(1.98-2.38)$ & 50.6 & $1.25(1.12-1.39)$ \\
\hline Multiple organs/regions & 19.8 & $2.25(1.99-2.55)$ & 40.3 & $1.00(0.85-1.17)$ \\
\hline \multicolumn{5}{|c|}{ Means of transportation to the hospital } \\
\hline Bus/van (public transport) & 4.9 & 1.00 & 32.0 & 1.00 \\
\hline On foot & 9.4 & $1.92(1.48-2.49)$ & 39.9 & $1.25(0.92-1.70)$ \\
\hline Private vehicle & 8.8 & $1.81(1.51-2.17)$ & 42.3 & $1.32(1.07-1.63)$ \\
\hline SAMU/Ambulance/Rescue & 20.4 & $4.18(3.43-5.10)$ & 51.7 & $1.62(1.31-2.01)$ \\
\hline Police car & 14.9 & $3.05(2.01-4.60)$ & 37.5 & $1.17(0.90-1.52)$ \\
\hline Other & 10.0 & $2.05(1.46-2.88)$ & 35.3 & $1.10(0.72-1.70)$ \\
\hline \multicolumn{5}{|l|}{ Period of visit } \\
\hline Daytime & 6.5 & 1.00 & 29.8 & 1.00 \\
\hline Nighttime & 19.8 & $3.04(2.72-3.39)$ & 51.2 & $1.72(1.53-1.93)$ \\
\hline \multicolumn{5}{|l|}{ Day of visit } \\
\hline Monday to Friday & 7.3 & 1.00 & 35.8 & 1.00 \\
\hline Saturday and Sunday & 21.7 & $2.96(2.58-3.41)$ & 55.4 & $1.55(1.41-1.70)$ \\
\hline \multicolumn{5}{|l|}{ Outcome } \\
\hline Hospital discharge & 9.8 & 1.00 & 42.3 & 1.00 \\
\hline Hospital admission & 18.4 & $1.88(1.67-2.11)$ & 46.9 & $1.11(0.99-1.23)$ \\
\hline Outpatient referral & 13.6 & $1.38(1.14-1.68)$ & 46.5 & $1.10(0.94-1.29)$ \\
\hline Evasion & 17.4 & $1.78(1.32-2.38)$ & 48.6 & $1.15(0.85-1.55)$ \\
\hline Death & 14.6 & $1.49(0.67-3.35)$ & 33.0 & $0.78(0.37-1.65)$ \\
\hline
\end{tabular}

Source: MS, SVS, Brazilian Surveillance System for Violence and Accidents (Sistema de Vigilância de Violências e Acidentes-VIVA survey), 2011. ${ }^{\mathrm{a}}$ Except Manaus, in the state of Amapá, and São Paulo, in the state of São Paulo; ${ }^{\mathrm{b}}$ Absolute number of observations; ${ }^{c}$ Weighted Percentage. PR: prevalence ratio; 95\% CI: 95\% confidence interval. Statistically significant differences $(\mathrm{p}<0.05)$ are in bold.

ant risk factors for violence (assault, homicide, suicide), traffic accidents, and work-related accidents, among others ${ }^{15,17}$.

The presence of alcohol in the bloodstream causes several neuromotor changes, depending on the concentration. Even at low doses $(0.3$ $\mathrm{dg} / \mathrm{L}$, or $1 \mathrm{drink}$ ), alcohol can result in decreased attention, misperception of speed, euphoria, and difficulty discerning distinct luminance differences. Higher concentrations progressively impair decision-making by interfering with reflexes and normal behavior and can lead to intoxication, drowsiness, and even alcoholic coma ${ }^{18}$.

The results of the current study corroborate the association between alcohol consumption and external causes, including accidents and violence, as has been widely reported in the literature $^{1-3,13,14}$. Among the many problems resulting from alcohol use, motor vehicle accidents involv- ing cars, motorcycles, and trucks occupy a prominent place. In the United States, for every 10 car accidents, 1.5 involves alcohol consumption. Drunk driving is one of the main consequences of the inappropriate use of alcohol and increases the risk of traffic accidents ${ }^{18}$.

Previous WHO studies have reported even higher rates: up to $20 \%$ of deaths from traffic accidents have been associated with high blood alcohol levels in high-income countries, and $33 \%-69 \%$ of deaths have been associated with alcohol use in low- and medium-income countries $^{19}$. Previous studies conducted in São Paulo have shown that $42.5 \%$ of homicide victims who were subjected to toxicology tests had consumed alcohol $^{20}$. In Curitiba, state of Paraná, 50.2\% of the victims of interpersonal assault and accidents with firearms or bladed weapons were under the influence of alcohol ${ }^{21}$. Moreover, studies con- 


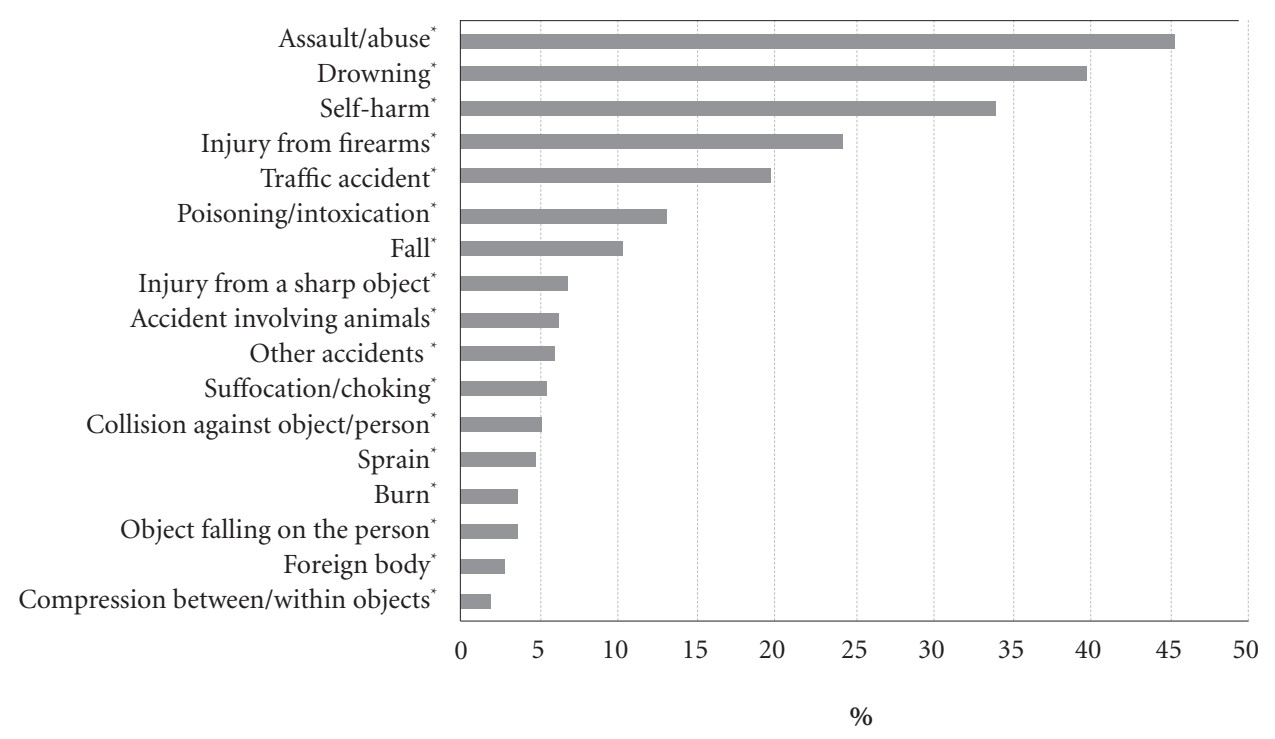

Figure 2. Distribution of self-reported alcohol consumption among patients who received emergency care per type of occurrence-Capitals ${ }^{\mathrm{a}}$ and the Federal District, Brazil, 2011.

Source: MS, SVS, Brazilian Surveillance System for Violence and Accidents (Sistema de Vigilância de Violências e Acidentes-VIVA survey), 2011. a Except Manaus, in the state of Amapá, and São Paulo, in the state of São Paulo. " p < 0.05 (Pearson chi-square test), using as a reference the percentage of self-reported alcohol consumption among patients who received emergency care for compression between/within objects.

ducted in Diadema, in the state of São Paulo, indicated a significant decrease in the number of violent deaths after restricting the sale of alcoholic beverages and closing the bars earlier at night ${ }^{22}$.

The sociodemographic characteristics described herein related to alcohol consumption and external causes (male gender, young age, low socioeconomic level, and low education level) have also been reported in national and international studies ${ }^{13,14,19}$.

External factors are important causes of morbidity and mortality among young men and strongly contribute to the reduction in life expectancy among men ${ }^{23}$. Occurrences among low-income and less-educated groups have also been described in other studies, confirming the social inequity and inequality of this outcome. Accordingly, low-income populations live in the suburbs, which have less public safety, increased population density, and increased vulnerabili$\mathrm{ty}^{19,23}$.

The increased occurrence of events on weekends and at night is also compatible with results from the literature, possibly because it is the most common time for gatherings, parties, and celebrations, which can lead to increased alcohol consumption and risk of occurrences ${ }^{19}$.
One the limitations of the study involved sample representativeness because the study included public urgent/emergency care services from 24 state capitals and the Federal District, which precluded making inferences about the entire Brazilian population. In addition, the study was conducted in a single month, which precluded the analysis of the seasonality of these events. Even with these limitations, emergency care in general was provided in public services because they are better equipped to provide care for external causes, and these results were consistent with those reported in the literature ${ }^{1,3,5,13,17}$. In addition, VIVA data fill an important gap by providing information on violence- and accident-related emergency visits and have supported violence prevention policies in Brazil.

The results presented herein reinforce the global discussions on the importance of establishing policies and legal measures to restrict alcohol consumption and motor vehicle driving, to limit advertisements on alcohol, and to create laws to regulate the operation of liquor stores ${ }^{14,24-26}$. Considering these findings, preventive measures should target population segments consisting primarily of men, individuals of black/ brown ethnicity, those with less education, those 
living in vulnerable situations (villagers, Quilombola communities, homeless), motor vehicle drivers, and participants of festive events-particularly on weekends.

Other measures are noteworthy, such as the launch of the Plan to Combat Chronic Non-Communicable Diseases (Plano de Enfrentamento de Doenças Crônicas Não Transmissíveis) $)^{25,26}$ in 2011,which established goals for the decrease of alcohol consumption and indicated the best strategies to decrease alcohol consumption as recommended by the $\mathrm{WHO}^{27}$ : a) strengthen the implementation of pricing policies and raise taxes on products derived from tobacco and alcohol to decrease consumption; b) support the intensification of surveillance measures associated with the sale of alcoholic beverages to minors ( $<$ 18 years); c) strengthen educational measures of the School Health Program (Programa Saúde na Escola/PSE) to prevent and limit tobacco use and alcohol abuse; and d) support local initiatives to control the sale of alcohol, establishing limited periods for sale in bars and similar places.

Other important public policy measures involved bans on drinking and driving (Prohibition Law No. 11705/2008 ${ }^{28}$; New Prohibition Law No. $12.760 / 2012^{29}$ ), which resulted in decreased alcohol consumption after the publication of laws on alcohol use and responsible driving ${ }^{30,31}$. The debate involving government, legislatures, health professionals, education professionals, society, families, and young people is essential to improve public policies and regulatory frameworks related to alcohol consumption.

More recently, other initiatives have included the Road Safety Program, known in Brazil as 'Programa Vida no Trânsito', a partnership involving the Ministry of Health, National Traffic Department (Departamento Nacional de Trânsito-Denatran), Ministry of Justice, PAHO, WHO, and Bloomberg Foundation, among other partners working in conjunction to promote the decrease in the number of traffic accidents, in addition to the 2011-2020 Road Safety Plan ${ }^{32}$.

\section{Conclusion}

The VIVA survey highlights the importance of the correlation between alcohol consumption and external causes, particularly cases of violence/ assault, half of which are associated with alcohol consumption. The survey allowed the identification of events not previously identified by the SIH/ SUS system or by the mortality information system (Sistema de Informação de Mortalidade/SIM) and combined all visits to urgency/emergency care units, including less severe cases. Therefore, the VIVA survey has supported local planning to the extent that managers and local teams understand the reality of these services and the circumstances underlying these events and can thus provide more effective strategies for the prevention of external causes and the promotion of health.

\section{Collaborators}

MDM Mascarenhas and ACM Neves participated in the study conception, design, data analysis, and manuscript preparation; RA Monteiro da Silva, MMA da Silva, and DC Malta contributed to data analysis and interpretation and manuscript review. All authors reviewed the text and approved the final version. 


\section{References}

1. World Health Organization (WHO). Alcohol and injuries: emergency departments studies in an international perspective. Geneva: WHO; 2009.

2. World Health Organization (WHO). Guidelines for conducting community surveys on injuries and violence. Geneva: WHO; 2004.

3. World Health Organization (WHO). World report on violence and health. Geneva: WHO; 2002.

4. Pan American Health Organization (PAHO). Prevention of alcohol-related injuries in the Americas: from evidence to policy action. Washington: PAHO; 2013.

5. Fraade-Blanar L, Concha-Eastman A, Baker T. Injury in the Americas: the relative burden and chalenge. Rev Panam Salud Publica 2007; 22(4):254-259.

6. Laranjeira $\mathrm{R}$, organizador. I Levantamento nacional sobre os padrões de consume de álcool na população brasileira. Brasília: SEAND; 2007.

7. Moura EC, Malta DC. Consumo de bebidas alcoólicas na população adulta brasileira: características sociodemográficas e tendência. Rev Bras Epidemiol 2011; 14(Supl. 1):61-70.

8. Gawryszewski VP, Silva MMA, Malta DC, Mascarenhas MDM, Costa VC, Matos SG, Moraes Neto OL, Monteiro RA, Gazal-Carvalho C, Magalhães ML. A proposta da rede de serviços sentinela como estratégia de vigilância de violências e acidentes. Cien Saude Colet 2006; 11(Supl.):1269-1278.

9. Brasil. Ministério da Saúde (MS). Viva: vigilância de violências e acidentes, 2006 e 2007. Brasília: MS; 2009.

10. Brasil. Ministério da Saúde (MS). Viva: vigilância de violências e acidentes, 2008 e 2009. Brasília: MS; 2010.

11. Brasil. Ministério da Saúde (MS). Viva: Vigilância de Violências e Acidentes, 2009, 2010 e 2011. Brasília: MS; 2013.

12. Brasil. Ministério da Saúde (MS). Portaria no 737, de 16 de maio de 2001. Institui a política nacional de redução da morbimortalidade por acidentes e violências. Diário Oficial da União 2001; 18 mai.

13. World Health Organization (WHO). International guide for monitoring alcohol consumption and related harm. Geneva: WHO; 2002.

14. World Health Organization (WHO). Strategies to reduce the harmful use of alcohol. Geneva: WHO; 2008. [acessado 2013 abr 10]. Disponível em: http://apps. who.int/gb/ebwha/pdf_files/A61/A61_13-en.pdf

15. Mascarenhas MDM, Malta DC, Silva MMA, GazalCarvalho C, Monteiro RA, Morais Neto OL. Consumo de álcool entre vítimas de acidentes e violências atendidas em serviços de emergência no Brasil, 2006 e 2007. Cien Saude Colet 2009; 14(5):1789-1796.

16. Brasil. Ministério da Saúde (MS). Vigitel 2012: Vigilância de fatores de risco e proteção para doenças crônicas por inquérito telefônico. Brasília: MS; 2013.

17. Barros MBA, León LM, Oliveira HB, Dalgalarrondo P, Botega NJ. Perfil do consumo de bebidas alcoólicas: diferenças sociais e demográficas no Município de Campinas, Estado de São Paulo, Brasil, 2003. Epidemiol Serv Saúde 2008;17(4):259-270.

18. National Highway Traffic Safety Administration. A review of the literature on the effects of low doses of alcohol on driving-related skills. [acessado 2008 jan 22]. Disponível em:http://www.nhtsa.dot.gov
19. World Health Organization (WHO). Beber e dirigir: manual de segurança no trânsito para profissionais de trânsito e saúde. Genebra: WHO; 2007.

20. Gazal-Carvalho C, Carlini-Cotrim B, Silva OA, Sauaia N. Prevalência de alcoolemia em vítimas de causas externas admitidas em centro urbano de atenção ao trauma. Rev Saude Publica 2002; 36(1):47-54.

21. Freitas EAM, Mendes ID, Oliveira LCM. Ingestão alcoólica em vítimas de causas externas atendidas em um hospital geral universitário. Rev Saude Publica 2008; 42(5):813-821.

22. Duailibi S, Ponicki W, Pinsky I, Laranjeira R, Raw M. The effect of restricting opening hours on alcohol related violence. Am J Public Health 2007; 97(12):22762280.

23. Brasil. Ministério da Saúde (MS). Saúde Brasil 2012: uma análise da situação de saúde e dos 40 anos do Programa Nacional de Imunizações. Brasília: MS; 2013.

24. McMillan GP, Lapham S. Effectiveness of bans and laws in reducing traffic deaths: legalized sunday packaged alcohol sales and alcohol-related traffic crashes and crash fatalities in New Mexico. Am J Public Health. 2006; 96:1944-1948.

25. Brasil. Ministério da Saúde (MS). Plano de ações estratégicas para o enfrentamento das doenças crônicas não transmissíveis (DCNT) no Brasil, 2011-2022. Brasília: MS; 2011. [acessado 2012 jun 17]. Disponível em: http://portal.saude.gov.br/portal/saude/profissional/ area.cfm?id_area $=1818$

26. Malta DC, Morais Neto OL, Silva Junior JB. Apresentação do plano de ações estratégicas para o enfrentamento das doenças crônicas não transmissíveis no Brasil, 2011 a 2022. Epidemiol Serv Saúde 2011; 20(4):425-438.

27. World Health Organization (WHO). Global status report on non-communicable diseases 2010. Geneva: WHO; 2011.

28. Brasil. Lei n. 11.705, de 19 de junho de 2008. Dispõe sobre o consumo de bebida alcoólica por condutor de veículo automotor, e dá outras providências. Diário Oficial da União 2008; 20 jun.

29. Brasil. Lei n. 12.760, de 20 de dezembro de 2012. Altera a Lei no 9.503, de 23 de setembro de 1997, que institui o Código de Trânsito Brasileiro. Diário Oficial da União 2012; 21 dez.

30. Moura EC, Malta DC, Morais Neto OL, Penna GO, Temporão JG. Direção de veículos motorizados após consumo abusivo de bebidas alcoólicas, Brasil, 2006 a 2009. Rev Saude Publica 2011; 43(Supl.):891-894.

31. Malta DC, Bernal RTI, Silva MMA, Claro RM, Silva Júnior JB, Reis AAC. Consumo de bebidas alcoólicas e direção de veículos, balanço da lei seca - Brasil, 2007 a 2013. Rev Saude Publica 2014; 48(4):692-966.

32. Morais Neto OL, Silva MMA, Lima CM, Malta DC, Silva Júnior JB. Projeto Vida no Trânsito: avaliação das ações em cinco capitais brasileiras, 2011-2012. Epidemiol Serv Saúde 2013; 22(3):373-382.

Article submitted 09/24/2013

Approved 10/09/2014

Final version submitted 10/11/2014 